\title{
Author Correction: Hospital Admissions due to Dysglycaemia and Prescriptions of Antidiabetic Medications in England and Wales: An Ecological Study
}

Abdallah Y. Naser · Qian Wang · Lisa Y. L. Wong · Jenni Ilomaki ·

J. Simon Bell · Gang Fang · Ian C. K. Wong · Li Wei

Published online: January 4, 2018

(c) The Author(s) 2018. This article is an open access publication

Author Correction: Diabetes Ther

https://doi.org/10.1007/s13300-017-0349-1

In the original publication, the fifth author's name was incorrectly published as Simon J. Bell. The correct name should read as 'J. Simon Bell'.

In the affiliations, the fifth author's name was incorrectly published as S. J. Bell. The correct name should read as J. S. Bell.

In the disclosures, the fifth author's name was incorrectly published as Simon J. Bell. The correct name should read as 'J. Simon Bell'.

The original article was corrected.

The original article can be found online at https://doi. org/10.1007/s13300-017-0349-1.

\footnotetext{
A. Y. Naser · I. C. K. Wong · L. Wei ( $₫)$

Research Department of Practice and Policy, UCL

School of Pharmacy, London, UK

e-mail: 1.wei@ucl.ac.uk

Q. Wang

Beijing Tongren Eye Center, Capital Medical

University, Beijing, China

L. Y. L. Wong

UCL Institute of Child Health, London, UK

J. Ilomaki · J. S. Bell

Centre for Medicine Use and Safety, Monash

University, Monash, Australia

G. Fang

Division of Pharmaceutical Outcomes and Policy, Eshelman School of Pharmacy, Chapel Hill, NC, USA
}

Open Access. This article is distributed under the terms of the Creative Commons Attribution-NonCommercial 4.0 International License (http://creativecommons.org/licenses/ by-nc/4.0/), which permits any noncommercial use, distribution, and reproduction in any medium, provided you give appropriate credit to the original author(s) and the source, provide a link to the Creative Commons license, and indicate if changes were made. 